\title{
Structural characterization of alloxazine and substituted isoalloxazines: NMR and X-ray crystallography
}

\author{
$\mathbf{M}^{\mathrm{a}}$ Ángeles Farrán ${ }^{a^{*}}$, Rosa $^{\mathrm{a}}$ Claramunt $^{a^{*}}$, Concepción López $^{a^{*}}$, Elena Pinilla ${ }^{b}$, \\ $\mathbf{M}^{\mathrm{a}}$ Rosario Torres, ${ }^{b}$ and José Elguero ${ }^{c}$ \\ ${ }^{a}$ Departamento de Química Orgánica y Bio-Orgánica, Facultad de Ciencias, Universidad \\ Nacional de Educación a Distancia (UNED), Senda del Rey 9, 28040 Madrid, Spain \\ ${ }^{b}$ Departamento de Química Inorgánica I, Facultad de Ciencias Químicas, Universidad \\ Complutense de Madrid (UCM), 28040 Madrid, Spain \\ ${ }^{c}$ Instituto de Química Médica, Consejo Superior de Investigaciones Científicas (CSIC) Juan de \\ la Cierva 3, 28006, Madrid, Spain \\ E-mails: afarran@bec.uned.es,rclaramunt@ccia.uned.es,clopez@ccia.uned.es
}

\section{Dedicated to Professor Joan Bosch on the occasion of his $60{ }^{\text {th }}$ anniversary}

\begin{abstract}
10-Methylisoalloxazine (1), 7,10-dimethylisoalloxazine (2), 3,7,10-trimethylisoalloxazine (3), 10-hexyl-7,8-dimethylisoalloxazine (4) and 10-hexyl-8-hydroxyisoalloxazine (5) have been studied by multinuclear magnetic resonance spectroscopy in solid state and in solution, comparatively to alloxazine (6). Tautomerism in such derivatives has been discussed on the basis of the calculated stabilities of the different tautomers and their heats of formation at the B3LYP/6-31G** level. The crystalline structures of compounds 2 and $\mathbf{4}$ have been determined.
\end{abstract}

Keywords: Isoalloxazines, tautomerism, ${ }^{13} \mathrm{C},{ }^{15} \mathrm{~N}$ CPMAS NMR, hydrogen-bonds, X-ray

\section{Introduction}

Isoalloxazines are the chemically active structures in the naturally occurring flavins. Flavins act as redox co-factors in flavoenzymes under two possible forms FMN (Flavin Mononucleotide) and FAD (Flavin Adenine Dinucleotide), both derived for riboflavin (vitamin $\mathrm{B}_{2}$ ) (Figure 1). ${ }^{1}$ They are versatile redox systems that are capable of accepting and transferring one or two electrons to other molecules. Still, much remains to be understood about their structural features in the active center of different flavoenzymes, therefore simple model studies in the solid state could bring some light into their characteristics. 


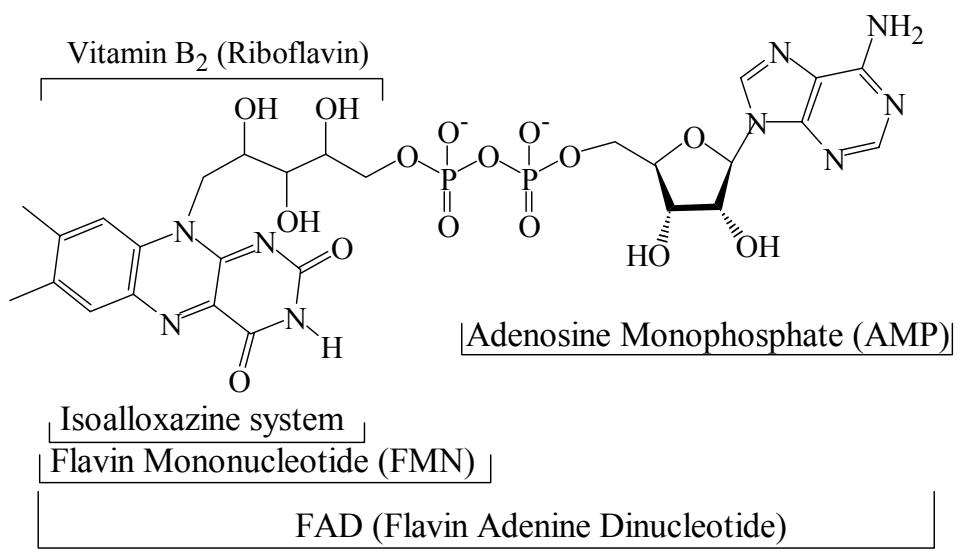

Figure 1. Flavin cofactors

We report here the structural characterization by multinuclear NMR in solid state and in solution of five isoalloxazines (1-5), comparatively to alloxazine (6), as well as X-ray studies on 7,10-dimethylisoalloxazine (2) and 10-hexyl-7,8-dimethylisoalloxazine (4).

\section{Results and Discussion}

According to the literature the redox properties of isoalloxazines are strongly influenced by substitution at position $7 ;^{2}$ it has also been reported that substitution in the benzene ring of isoalloxazines makes the entire molecule less planar. ${ }^{3}$ Therefore compounds 1-5 were prepared to study the influence of C-substitution from a structural point of view.<smiles>Cn1c2nc(=O)[nH]c(=O)c-2nc2ccccc21</smiles>

$\mathrm{C}_{6} \mathrm{H}_{13}$

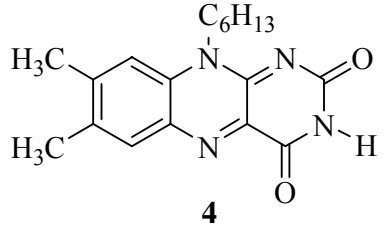<smiles>Cc1ccc2c(c1)nc1[nH]c(=O)c(=O)nc-1n2C</smiles>

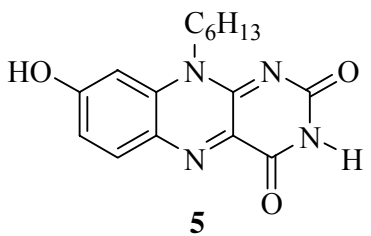<smiles>Cc1ccc2c(c1)nc1c(=O)n(C)c(=O)nc-1n2C</smiles><smiles>O=c1[nH]c(=O)c2nc3ccccc3nc2[nH]1</smiles>

Figure 2. Isoalloxazines (1-5) and alloxazine (6).

The procedure of Yoneda et al. whose synthetic route is shown in Scheme 1 was used, ${ }^{4}$ starting from the corresponding substituted anilines that reacted with 6-chlorouracil or 6-chloro- 
3-methyluracil to afford the 6-substituted pyrimidine-2,4(1H,3H)-dione derivatives 7a-e. Their subsequent treatment with sodium nitrite in acetic acid yielded the isoalloxazine-5-oxides 8a-e, which after reaction with sodium dithionate afford the isoalloxazines 1-5. ${ }^{4-6}$ All steps occurred with good yields and the isolation procedures were straightforward (see experimental part).

In the literature several solution NMR studies of alloxazine, isoalloxazines ${ }^{7-9}$ and riboflavine esters have been reported. ${ }^{10}$ However, to our knowledge no study of these compounds in the solid state has yet been described.

Isoalloxazines 1-3 are highly insoluble in most common organic solvents but isoalloxazines $\mathbf{4}$ and $\mathbf{5}$ are more soluble due to the $N$-hexyl chain in position 10 .<smiles>[R]Nc1ccc([R4])c([R3])c1</smiles><smiles>[R]n1c(=O)cc(Cl)[nH]c1=O</smiles><smiles>[R3]c1ccc(N([R2])c2cc(=O)n([R1])c(=O)[nH]2)cc1[R3]</smiles>

\begin{tabular}{lcllll} 
& $\mathrm{R}_{1}$ & $\mathrm{R}_{2}$ & $\mathrm{R}_{3}$ & $\mathrm{R}_{4}$ & Isoalloxazines \\
\hline $\mathbf{a}$ & $\mathrm{H}$ & $\mathrm{CH}_{3}$ & $\mathrm{H}$ & $\mathrm{H}$ & $\mathbf{1}$ \\
$\mathbf{b}$ & $\mathrm{H}$ & $\mathrm{CH}_{3}$ & $\mathrm{H}$ & $\mathrm{CH}_{3}$ & $\mathbf{2}$ \\
c & $\mathrm{CH}_{3}$ & $\mathrm{CH}_{3}$ & $\mathrm{H}$ & $\mathrm{CH}_{3}$ & $\mathbf{3}$ \\
d & $\mathrm{H}$ & $\mathrm{C}_{6} \mathrm{H}_{13}$ & $\mathrm{CH}_{3}$ & $\mathrm{CH}_{3}$ & $\mathbf{4}$ \\
e & $\mathrm{H}$ & $\mathrm{C}_{6} \mathrm{H}_{13}$ & $\mathrm{OH}$ & $\mathrm{H}$ & $\mathbf{5}$
\end{tabular}<smiles>[R3]c1cc2nc3c(=O)n([R1])c(=O)nc-3n([R2])c2cc1[R3]</smiles>

1-5

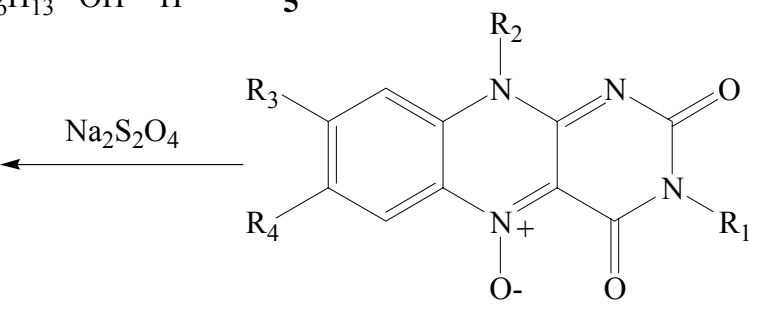

8a-8e

Scheme 1. Synthetic route to obtain isoalloxazines 1-5

Solution ${ }^{13} \mathrm{C}$ NMR spectra were run in DMSO- $\mathrm{d}_{6}$, and the results are shown in Table 1. In all cases the signals were assigned using ${ }^{1} \mathrm{H}_{-}{ }^{13} \mathrm{C}$ gs-HMQC and gs-HMBC experiments. An example for the 3,7,10-trimethylisoalloxazine (3), is given in Figure 3. 

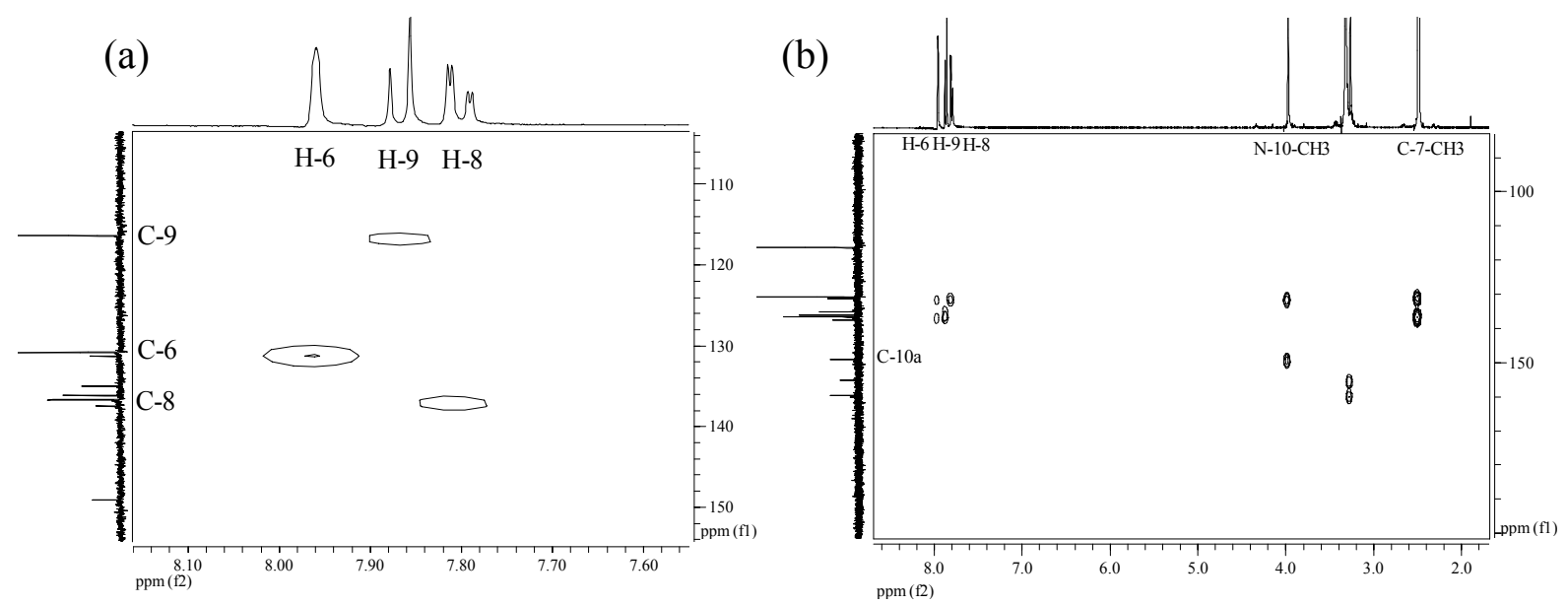

Figure 3. (a) ${ }^{1} \mathrm{H}-{ }^{13} \mathrm{C}$ gs- $\mathrm{HMQC}(\mathrm{b}){ }^{1} \mathrm{H}-{ }^{13} \mathrm{C}$ gs-HMBC for 3

The ${ }^{13} \mathrm{C}$ NMR chemical shifts in solution and in solid state of isoalloxazines 1-5 are in agreement with tautomer 10H-3H (Figure 8); the 3,7,10-trimethylisoalloxazine (3) representing the blocked model of such structure. The values between brackets shown in Table 1 quantify the methyl and hydroxyl substituent chemical shift effects and support the coherence of our data.

With regard to the pyrimidine-2,4-dione moiety, the $\delta$ of the carbon of the oxo group at position 4 is higher than the one found for the carbon at position-2, similarly to what was found for uracil itself. ${ }^{11}$

In Figure 4 we present the ${ }^{13} \mathrm{C}$ CPMAS NMR spectra of $\mathbf{3}$ and $\mathbf{6}$, respectively. As it can easily be observed, the most characteristic signal is $\mathrm{C}-10 \mathrm{a}$ which shifts upfield from a $\mathbf{1 0 H}-\mathbf{3 H}$ tautomer in the representative isoalloxazine (3) to a $\mathbf{1 H}-\mathbf{3 H}$ one in alloxazine (6). On the other hand carbons C-9a, C-4a and C-5a move downfield. 
Table 1. ${ }^{13} \mathrm{C}$-NMR chemical shifts ( $\delta$ in ppm) of substituted isoalloxazines (1-5) and alloxazine (6). In brackets are the substituent chemical shift effects.

\begin{tabular}{|c|c|c|c|c|c|c|c|c|c|c|}
\hline Comp & $\mathrm{C}-2$ & C-4 & $C-4 a$ & $C-5 a$ & C-6 & C-7 & C-8 & C-9 & C-9a & C-10a \\
\hline 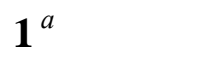 & 8 & & & & & & & & & \\
\hline$-d_{6}$ & {$[0$} & [0] & {$[($} & {$[0$} & {$[0]$} & {$[0$} & & & [0] & {$[0]$} \\
\hline $\begin{array}{l}\mathbf{1}^{b} \\
\text { CPMAS }\end{array}$ & 155.4 & 162.5 & 134.5 & 134.5 & 132.0 & 128.9 & 135.8 & 1149 & 33.1 & 150.5 \\
\hline$\underline{2}^{c}$ & 155.8 & 160.0 & 136.2 & 135.2 & 131.6 & 140.6 & 138.7 & 116.6 & 131.0 & 150.9 \\
\hline DMSO-d 6 & [0] & {$[+0.1]$} & {$[-2.7]$} & {$[+0.3]$} & [0] & {$[+14.3]$} & {$[+3.5]$} & {$[-0.2]$} & 6] & {$[-0.2]$} \\
\hline $\begin{array}{l}\mathbf{2}^{d} \\
\text { CPMAs }\end{array}$ & 160.0 & 160.0 & 136.2 & 135.0 & 127.9 & 140.6 & 137.6 & 120.9 & 0 & 150 \\
\hline $3^{e}$ & 155.1 & 159.6 & 136.3 & 135.1 & 130.7 & 137 & 136.7 & 116.9 & 131.2 & 149.0 \\
\hline MSO-d 6 & {$[-0.7]$} & {$[-0.3]$} & {$[-2.6]$} & {$[+0.1]$} & {$[-0.9]$} & & 5] & {$[+$} & 4] & {$[-2.1]$} \\
\hline${ }^{f}$ & 154.1 & 159.8 & 136.0 & 136.0 & 130.2 & 138.0 & 138.0 & 119.6 & 132.4 & 148.2 \\
\hline $4^{g}$ & 155.7 & 160.0 & 137.2 & 133.9 & 131.1 & 135 & 146.6 & 116.1 & 130.8 & 150.1 \\
\hline MSO-d 6 & {$[-0.1]$} & {$[+0.1]$} & {$[-1.7]$} & {$[-1.0]$} & {$[-0.5]$} & & {$[+11.4]$} & {$[-0.7]$} & {$[-2.8]$} & {$[-1.0]$} \\
\hline $\begin{array}{l}4^{h} \\
\mathrm{CPM}\end{array}$ & 157.8 & 159.6 & 138.1 & 135.3 & 131.3 & 1 & 8 & 17.9 & 31.3 & 148.8 \\
\hline $5^{i}$ & 155.8 & 160.3 & 135.1 & 130.2 & 134.2 & 117.7 & 165.5 & 99. & 133.3 & 150.5 \\
\hline DMSO-d $_{6}$ & {$[0]$} & {$[+0.4]$} & {$[-3.8]$} & {$[-4.7]$} & {$[+2.6]$} & {$[-8.6]$} & {$[+30.3]$} & {$[-17.0]$} & {$[-0.3]$} & {$[-0.6]$} \\
\hline $\mathbf{5}^{j}$ & 154.6 & 161.7 & 134.5 & 130.3 & 137.4 & 120.5 & 166.0 & 99.2 & 132.4 & 149.6 \\
\hline 6 & 150.1 & 160.4 & 146.8 & 139.2 & 130.1 & 128 & 323 & 126 & 142.6 & 131.6 \\
\hline DMSO-d $_{6}$ & {$[-5.7]$} & {$[+0.5]$} & {$[+7.9]$} & {$[+4.3]$} & {$[-1.5]$} & {$[+2.0]$} & {$[-1.9]$} & {$[+10.1]$} & {$[+9.0]$} & {$[-19.5]$} \\
\hline 6 & 150.4 & 156.4 & 144.7 & 140.5 & 132.8 & 131.2 & 137.2 & 127.1 & 141.9 & 131.2 \\
\hline
\end{tabular}

${ }^{a} \mathrm{Me}-10: 32.1 ;{ }^{b} \mathrm{Me}-10: 34.2 ;{ }^{c} \mathrm{Me}-10: 32.2, \mathrm{Me}-7: 20.2 ;{ }^{d} \mathrm{Me}-10: 32.9$, Me-7: $19.0 ;{ }^{e} \mathrm{Me}-3$ : 28.1, Me-10: 31.8, Me-7: 20.2; ${ }^{f}$ Me-3: 28.0, Me-10: 32.7, Me-7: 20.0; ${ }^{g}$ Hexyl: 44.2, 31.0, 26.5, 25.9, 18.8,14.0, Me-7: 20.6, Me-8: 22.0; ${ }^{h}$ Hexyl-10: 47.8, 30.0, 27.9, 22.7, 13.3, Me-7: 19.7, Me-8: 20.7; ${ }^{i}$ Hexyl-10: 44.3, 35.8, 31.0, 26.0, 22.1 ${ }^{j}$ Hexyl-10: 46.7, 35.0, 30.3, 27.2, 25.8, 16.3. 


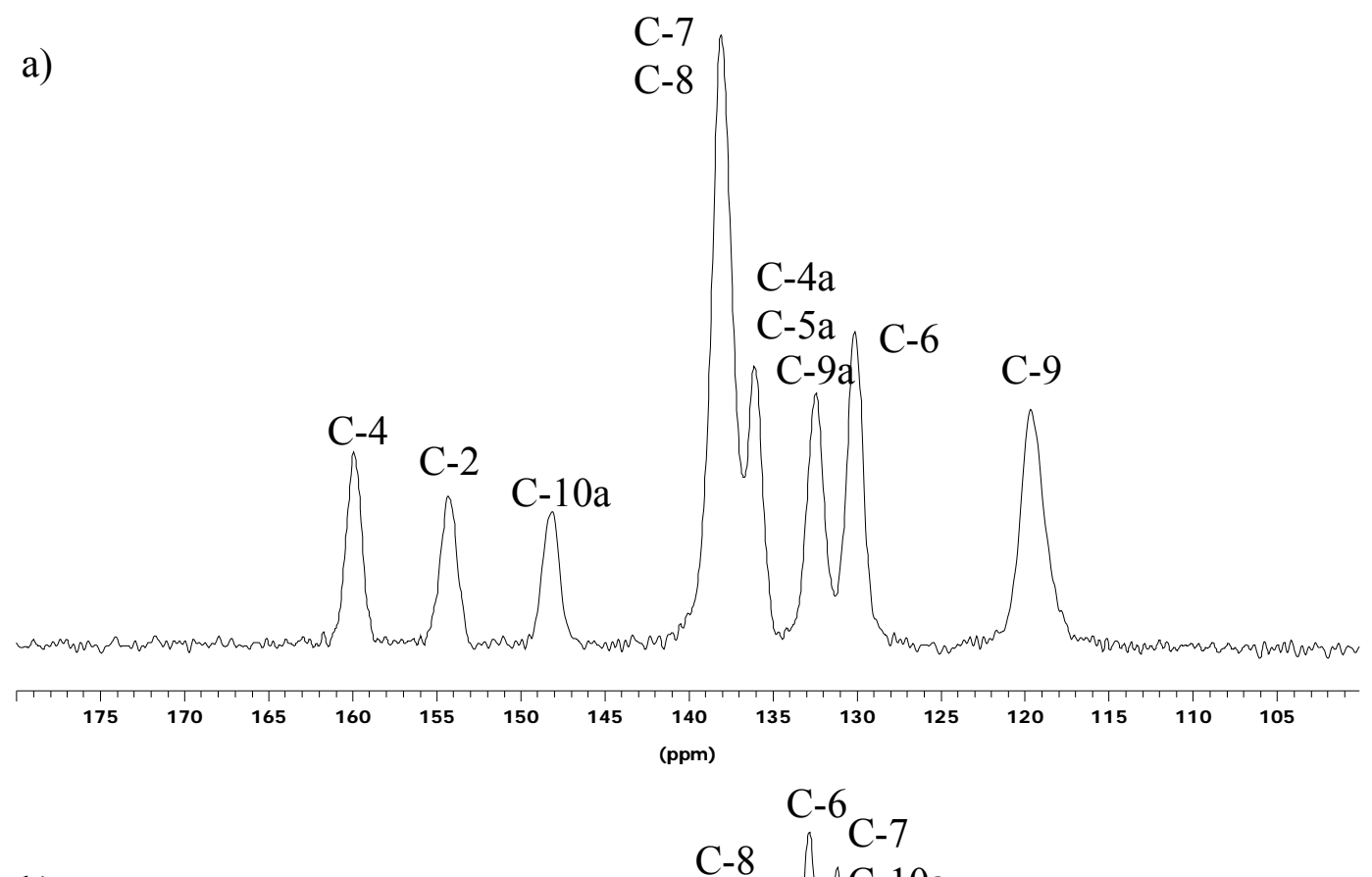

b)

Figure 4. ${ }^{13} \mathrm{C}$ CPMAS NMR expanded region (100-180 ppm): a) 3,7,10-trimethylisoalloxazine (3); b) alloxazine (6).

The ${ }^{15} \mathrm{~N}$ NMR chemical shifts in DMSO- $\mathrm{d}_{6}$ (Table 2) were determined by inverse detection using ${ }^{1} \mathrm{H}-{ }^{15} \mathrm{~N}$ gs-HMBC experiments (only $\mathrm{N}-3$ and $\mathrm{N}-10$ could be detected). We have reproduced in Figure 5 a typical gs-HMBC experiment that has allowed to assign the ${ }^{15} \mathrm{~N}$ resonances for the 3,7,10-trimethylisoalloxazine (3). 


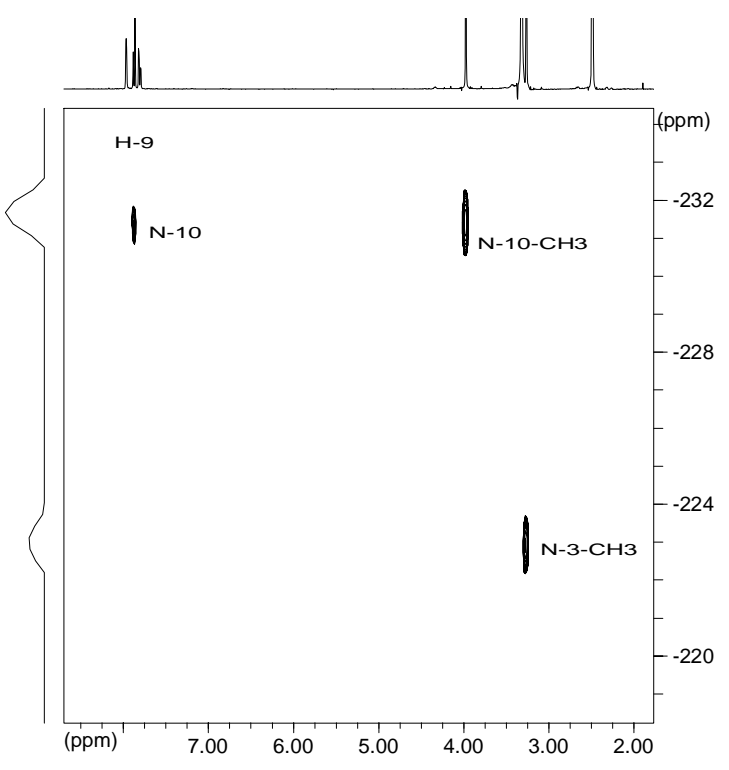

Figure 5. ${ }^{1} \mathrm{H}-{ }^{15} \mathrm{~N}$ gs-HMBC spectrum for 3.

Table 2. ${ }^{15} \mathrm{~N}$ - NMR chemical shifts ( $\delta$ in ppm) of substituted isoalloxazines (1-5) and alloxazine (6)

\begin{tabular}{|c|c|c|c|c|}
\hline Compound & $\mathrm{N}-1$ & $\mathrm{~N}-3$ & $\mathrm{~N}-5$ & N-10 \\
\hline $\begin{array}{c}\mathbf{1}^{a} \\
\text { CPMAS }\end{array}$ & -183.0 & -218.6 & $-36.0^{b}$ & -218.6 \\
\hline $\begin{array}{c}2 \\
\text { DMSO-d }_{6}\end{array}$ & $c$ & -219.3 & $c$ & -231.8 \\
\hline $\begin{array}{c}2 \\
\text { CPMAS }\end{array}$ & -183.0 & -218.6 & $-40.0^{b}$ & -223.7 \\
\hline $\begin{array}{c}3 \\
\text { DMSO- }_{6}\end{array}$ & $c$ & -222.9 & $c$ & -231.3 \\
\hline $\begin{array}{c}3 \\
\text { CPMAS }\end{array}$ & -181.3 & -218.3 & $-40.0^{b}$ & -226.6 \\
\hline $\begin{array}{c}4 \\
\text { DMSO-d }_{6}\end{array}$ & $c$ & -218.3 & $-40.0^{b}$ & -221.2 \\
\hline $\begin{array}{c}\mathbf{4} \\
\text { CPMAS }\end{array}$ & -180.0 & -212.4 & $c$ & -215.7 \\
\hline $\begin{array}{c}5^{a} \\
\text { CPMAS }\end{array}$ & -185.2 & -213.6 & $c$ & -219.3 \\
\hline $\begin{array}{c}\mathbf{6}^{a} \\
\text { CPMAS }\end{array}$ & -254.2 & -221.35 & -39.8 & -116.5 \\
\hline
\end{tabular}

${ }^{a}$ No signals could be detected in DMSO- $\mathrm{d}_{6}$ solution even using different delays for evolution of long-range couplings; ${ }^{b}$ Broad signal; ${ }^{c}$ Not detected 
When examining the ${ }^{15} \mathrm{~N}-\mathrm{NMR}$ data the main differences, between the $\mathbf{1 0 H}-\mathbf{3 H}$ tautomer and the 1H-3H one, lie on the chemical shifts of nitrogen atoms with values of $-254.2 \mathrm{ppm}$ for $\mathrm{N}-1$ and of $-116.5 \mathrm{ppm}$ for N-10 in alloxazine (6) and around $-182 \mathrm{ppm}$ for N-1 and in a range of -215.7/-231.8 ppm for $\mathrm{N}-10$ in isoalloxazines (1-5).

\section{X-Ray Crystallography}

Suitable crystals for X-ray diffraction experiments were obtained by crystallization from formic acid-water for 7,10-dimethylisoalloxazine (2) and dimethylsulfoxide-water for 10-hexyl-7,8dimethylisoalloxazine (4). All attempts to get appropriate crystals of compounds $\mathbf{1}, \mathbf{3}$ and 5 were unsuccessful.

Figure 6 shows an ORTEP perspective (40\% probability) of the molecular structures of 2 and 4, including the atom numbering. In both cases the molecules are planar within experimental error. The maximum deviation of the best least-square plane considering all atoms of the rings, is 0.183(3) for C12 in 2 and 0.049(4) for C11 in 4. Selected bond distances and angles are collected in Table 3 and as expected no appreciable differences in both compounds are observed. The influence of the hexyl group accounts only for the distinct packing modes, sheets in the case of compound 2 and one-dimensional in compound 4 (Fig. 7).

a)

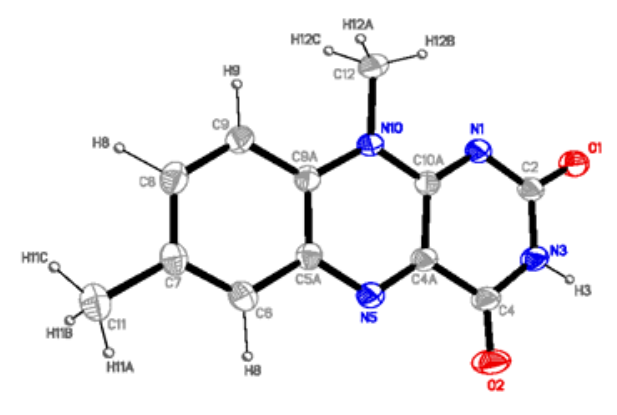

b)

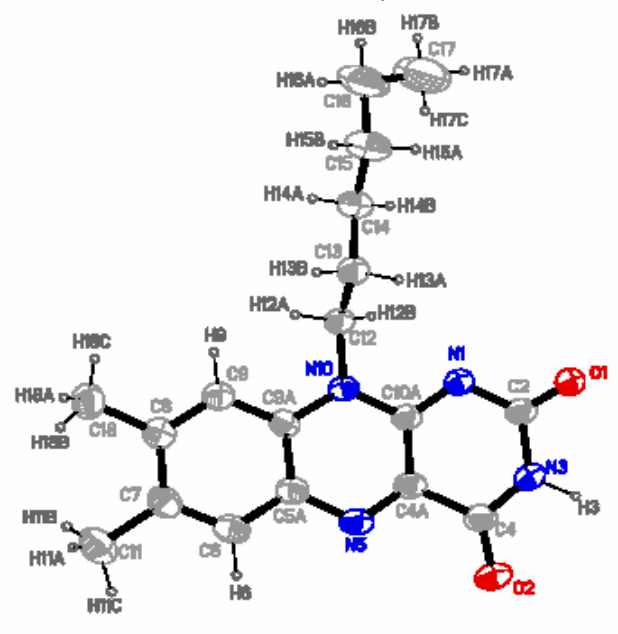

Figure 6. X-Ray molecular structure of: a) 7,10-dimethylisoalloxazine (2); b) 10-hexyl-7,8dimethylisoalloxazine (4)

As seen in Figure 7 both compounds present N3-H3...O1 intermolecular hydrogen bonds, which lead to dimers (Table 4). Additionally, in both isoalloxazines the $\mathrm{O} 2$ shows interaction between dimers, that in 2 lead to a broad slice parallel to (-1 03 ) plane and in 4 to a ribbon parallel to the $b$ axis. 
Table 3. Some selected bond lengths $[\AA]$ and angles $\left[{ }^{\circ}\right]$ for compounds 2 and 4

\begin{tabular}{ccc}
\hline & $\mathbf{2}$ & $\mathbf{4}$ \\
\hline $\mathrm{N} 1-\mathrm{C} 2$ & $1.369(3)$ & $1.363(3)$ \\
$\mathrm{N} 1-\mathrm{C} 10 \mathrm{~A}$ & $1.319(3)$ & $1.318(3)$ \\
$\mathrm{C} 2-\mathrm{O} 1$ & $1.225(3)$ & $1.226(3)$ \\
$\mathrm{N} 3-\mathrm{C} 2$ & $1.391(3)$ & $1.398(3)$ \\
N3-C4 & $1.367(3)$ & $1.362(3)$ \\
N5-C4A & $1.302(3)$ & $1.304(3)$ \\
N5-C5A & $1.371(3)$ & $1.369(3)$ \\
N10-C9A & $1.392(3)$ & $1.362(3)$ \\
N10-C10A & $1.366(3)$ & $1.362(3)$ \\
C10A-N1-C2 & $118.0(2)$ & $118.0(2)$ \\
N1-C2-O1 & $121.6(2)$ & $121.5(3)$ \\
O2-C4-N3 & $122.4(2)$ & $121.8(3)$ \\
\hline
\end{tabular}

Table 4. Hydrogen bonds for compounds 2 and $\mathbf{4}\left[\AA\right.$ and $\left.^{\circ}\right]$.

\begin{tabular}{clllll}
\hline Compound & $\mathrm{D}-\mathrm{H} \ldots \mathrm{A}$ & $\mathrm{d}(\mathrm{D}-\mathrm{H})$ & $\mathrm{d}(\mathrm{H} \ldots \mathrm{A})$ & $\mathrm{d}(\mathrm{D} \ldots \mathrm{A})$ & $<(\mathrm{DHA})$ \\
\hline $\mathbf{2}$ & $\mathrm{N} 3-\mathrm{H} 3 \ldots \mathrm{O} 1^{a}$ & $0.98(3)$ & $1.90(3)$ & $2.885(3)$ & $176(2)$ \\
& $\mathrm{C} 9-\mathrm{H} 9 \ldots \mathrm{O} 2^{b}$ & 1.00 & 2.38 & $3.164(3)$ & 134.7 \\
4 & $\mathrm{~N} 3-\mathrm{H} 3 \ldots 1^{c}$ & $1.01(3)$ & $1.81(3)$ & $2.817(3)$ & $172(3)$ \\
& $\mathrm{C} 9-\mathrm{H} 9 \ldots 2^{d}$ & 0.93 & 2.61 & $3.380(3)$ & 140.9 \\
\hline
\end{tabular}

${ }^{a}-\mathrm{x}-1,-\mathrm{y},-\mathrm{z}+1 ;{ }^{b}-\mathrm{x}+1 / 2, \mathrm{y}+1 / 2,-\mathrm{z}+3 / 2 ;{ }^{c}-\mathrm{x},-\mathrm{y}+3,-\mathrm{z} ;{ }^{d} \mathrm{x}, \mathrm{y}-1, \mathrm{z}$ 
a)

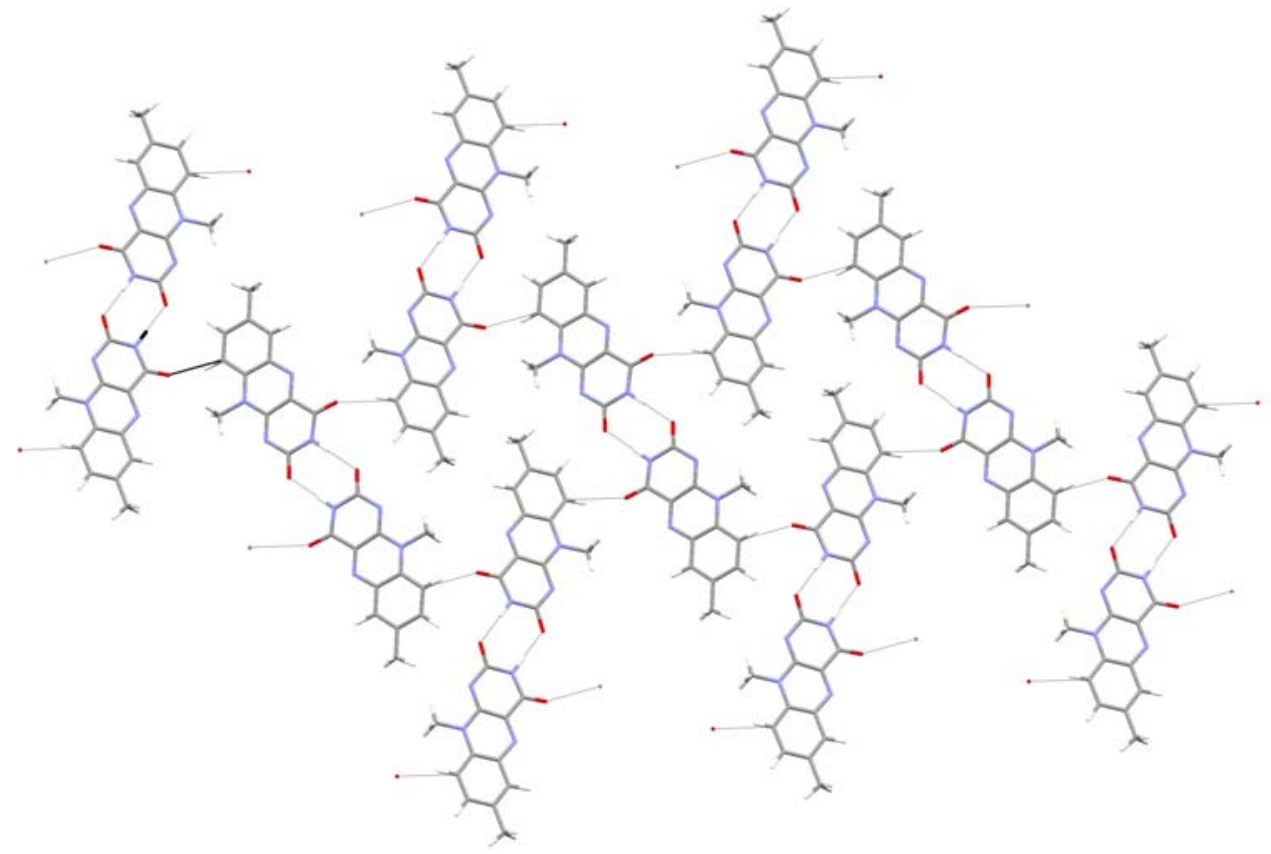

b)

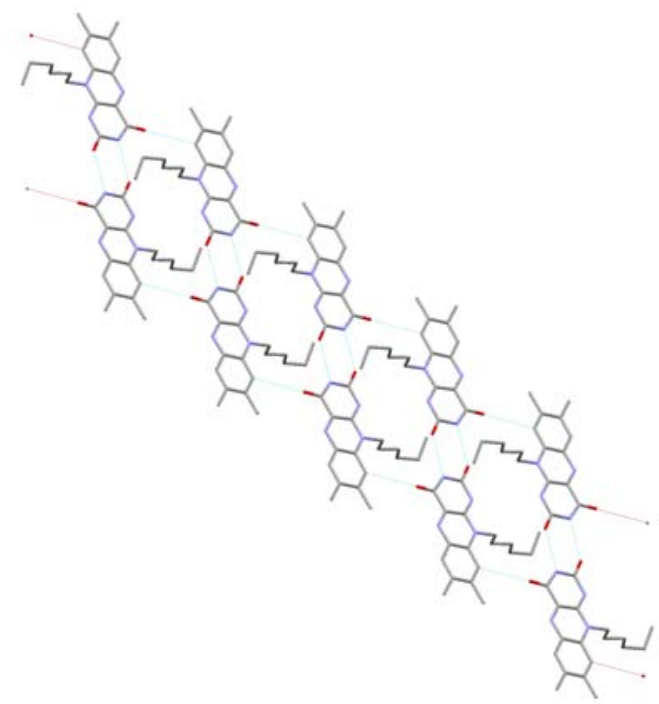

Figure 7. 2 D-network in the crystal structures of: a) isoalloxazine 2; b) isoalloxazine 4

Finally we have performed density functional calculations (B3LYP/6-31G** level) on the tautomeric forms of the alloxazine/isoalloxazine process (Figure 8 ) the results being gathered in Table 5. The most stable tautomer is $\mathbf{1 H}-\mathbf{3 H}$ that corresponding to what we have found for alloxazine (6), and the stability order in $\mathrm{kJ} \mathrm{mol}^{-1}$ is $\mathbf{1 H}-\mathbf{3 H}(0)>\mathbf{1 0 H}-\mathbf{3 H}(53.8)>\mathbf{1 H}-\mathbf{4 O H}$ $(57.2)>3$ H-2OH (63.3) > 1H-2OH (79.8) > 2OH-4OH (93.9) > 3H-5H (116.0) > 10H-4OH (126.3) > 10H-2OH (127.7). 
<smiles>O=c1[nH]c(=O)c2nc3ccccc3c(=O)nc2[nH]1</smiles>

10H-3H<smiles>O=c1[nH]c(=O)c2nc3ccccc3nc2[nH]1</smiles>

1H-3H<smiles></smiles>

3H-5H<smiles>O=c1nc(O)nc2[nH]c3ccccc3nc1-2</smiles>

10H-2OH<smiles>O=c1nc(O)[nH]c2nc3ccccc3nc12</smiles>

1H-2OH<smiles>O=c1[nH]c(O)nc2nc3ccccc3nc12</smiles>

3H-2OH<smiles>O=c1nc2[nH]c3ccccc3nc-2c(O)n1</smiles>
10H-4OH<smiles>O=c1nc(O)c2nc3ccccc3nc2[nH]1</smiles>

1H-4OH<smiles>Oc1nc(O)c2nc3ccccc3nc2n1</smiles>

2OH-4OH

Figure 8. Structures of the calculated tautomers (The most stable hydroxyl conformation is shown) 
Table 5. Absolute energies (Hartree), relative energies in brackets $\left(\mathrm{kJ} \mathrm{mol}^{-1}\right)$ and dipole moments (Debye) of the calculated tautomers

\begin{tabular}{|c|c|c|c|}
\hline Tautomers & & Energies & Dipole moments \\
\hline \multirow[t]{3}{*}{$10 \mathrm{H}-3 \mathrm{H}$} & & -754.180052 & 7.68 \\
\hline & $+\mathrm{ZPE}$ & -754.023254 & \\
\hline & & {$\left[+53.8 \mathrm{kJmol}^{-1}\right]$} & \\
\hline \multirow[t]{3}{*}{$10 \mathrm{H}-2 \mathrm{OH}$} & & -754.151545 & 10.62 \\
\hline & $+\mathrm{ZPE}$ & -753.995117 & \\
\hline & & {$\left[+127.7 \mathrm{kJmol}^{-1}\right]$} & \\
\hline \multirow[t]{3}{*}{$10 \mathrm{H}-4 \mathrm{OH}$} & & -754.151841 & 8.20 \\
\hline & $+\mathrm{ZPE}$ & -753.995638 & \\
\hline & & {$\left[+126.3 \mathrm{kJmol}^{-1}\right]$} & \\
\hline \multirow{3}{*}{ 1H-3H } & & -754.200712 & 4.25 \\
\hline & $+\mathrm{ZPE}$ & -754.043750 & \\
\hline & & {$[0]$} & \\
\hline \multirow[t]{3}{*}{$1 \mathrm{H}-2 \mathrm{OH}$} & & -754.169676 & 5.32 \\
\hline & $+\mathrm{ZPE}$ & -754.013350 & \\
\hline & & {$\left[+79.8 \mathrm{kJmol}^{-1}\right]$} & \\
\hline \multirow[t]{3}{*}{$1 \mathrm{H}-4 \mathrm{OH}$} & & -754.178653 & 4.95 \\
\hline & $+\mathrm{ZPE}$ & -754.021953 & \\
\hline & & {$\left[+57.2 \mathrm{kJmol}^{-1}\right]$} & \\
\hline \multirow[t]{3}{*}{$3 H-5 H$} & & -754.155919 & 9.58 \\
\hline & $+\mathrm{ZPE}$ & -753.999574 & \\
\hline & & {$\left[+116.0 \mathrm{kJmol}^{-1}\right]$} & \\
\hline \multirow[t]{3}{*}{$3 \mathrm{H}-2 \mathrm{OH}$} & & -754.176139 & 2.14 \\
\hline & $+\mathrm{ZPE}$ & -754.019651 & \\
\hline & & {$\left[+63.3 \mathrm{kJmol}^{-1}\right]$} & \\
\hline \multirow[t]{3}{*}{ 2OH-4OH } & & -754.164758 & 1.86 \\
\hline & $+\mathrm{ZPE}$ & -754.007999 & \\
\hline & & {$\left[+93.9 \mathrm{kJmol}^{-1}\right]$} & \\
\hline
\end{tabular}

\section{Conclusions}

Tautomerism of alloxazine and isoalloxazines has been discussed from a theoretical point of view by means of density functional calculations at the B3LYP/6-31G** level, concluding that the most stable form is the $\mathbf{1 H}-\mathbf{3 H}$ followed by the $\mathbf{1 0 H}-\mathbf{3 H}$, of much higher energy $\left(53.8 \mathrm{~kJ} \mathrm{~mol}^{-1}\right)$. These results are supported by multinuclear NMR spectroscopy in solution and in the solid state, as well as by X-ray diffraction analysis. 


\section{Experimental Section}

General. Alloxazine 6 was purchased from ALDRICH and used as received after checking its purity by DSC (M.p. $377.2^{\circ} \mathrm{C}$ ). All compounds were dried at $100^{\circ} \mathrm{C}$ using phosphorus pentoxide as drying agent. Melting points for alloxazine 6 and isoalloxazines 1-5 were determined by DSC on a Seiko DSC 220C connected to a Model SSC5200H Disk Station and for the other compounds a ThermoGalen hot stage microscope was used. Isoalloxazines 1-5 give correct microanalytical results for carbon, hydrogen, and nitrogen (Microanalytical Service of the Complutense University on a Perkin-Elmer 240 analyzer). The exact mass of 4 and 5 was determined by high resolution mass spectrometry at $70 \mathrm{eV}$ using the electron impact mode with a VG AutoSpec Spectrometer.

NMR parameters. Solution. The spectra were recorded on a Bruker DRX 400 (9.4 Tesla, $400.13 \mathrm{MHz}$ for ${ }^{1} \mathrm{H}, 100.62 \mathrm{MHz}$ for ${ }^{13} \mathrm{C}$ and $40.56 \mathrm{MHz}$ for ${ }^{15} \mathrm{~N}$ ) spectrometer with a $5-\mathrm{mm}$ inverse-detection $\mathrm{H}$-X probe equipped with a z-gradient coil for ${ }^{1} \mathrm{H},{ }^{13} \mathrm{C}$ and ${ }^{15} \mathrm{~N}$. In all cases the spectra were recorded at $300 \mathrm{~K}$. Chemical shifts $(\delta$ in ppm) are given from internal solvent, DMSO-d $\mathrm{d}_{6} 2.49$ and $\mathrm{CDCl}_{3} 7.26$ for ${ }^{1} \mathrm{H}$ and 39.5 and 77.0 for ${ }^{13} \mathrm{C}$, and nitromethane $(0.00)$ for ${ }^{15} \mathrm{~N}$ NMR were used as external references. Typical parameters for ${ }^{1} \mathrm{H}$ NMR spectra were spectral width $6400 \mathrm{~Hz}$, pulse width $7.5 \mu \mathrm{s}$ at an attenuation level of $0 \mathrm{~dB}$ and resolution $0.39 \mathrm{~Hz}$ per point. Typical parameters for ${ }^{13} \mathrm{C}$ NMR spectra were spectral width $20500 \mathrm{~Hz}$, pulse width 10.6 $\mu \mathrm{s}$ at an attenuation level of $-6 \mathrm{~dB}$ and resolution $0.63 \mathrm{~Hz}$ per point; WALTZ-16 was used for broadband proton decoupling; the FIDS were multiplied by an exponential weighting $(\mathrm{lb}=1 \mathrm{~Hz})$ before Fourier transformation. 2D $\left({ }^{1} \mathrm{H}-{ }^{1} \mathrm{H}\right)$ gs-COSY and inverse proton detected heteronuclear shift correlation spectra, $\left({ }^{1} \mathrm{H}_{-}{ }^{13} \mathrm{C}\right)$ gs-HMQC, $\left({ }^{1} \mathrm{H}_{-}{ }^{13} \mathrm{C}\right)$ gs-HMBC and $\left({ }^{1} \mathrm{H}^{-15} \mathrm{~N}\right)$ gs-HMBC, were acquired and processed using standard Bruker NMR software and in non-phase-sensitive mode. ${ }^{12}$ Gradient selection was achieved through a 5\% sine truncated shaped pulse gradient of $1 \mathrm{~ms}$.

Solid state. ${ }^{13} \mathrm{C}(100.73 \mathrm{MHz})$ and ${ }^{15} \mathrm{~N}(40.60 \mathrm{MHz})$ CPMAS NMR spectra were obtained on a Bruker WB 400 spectrometer at $300 \mathrm{~K}$ using a $4 \mathrm{~mm}$ DVT probehead. Samples were carefully packed in a 4-mm diameter cylindrical zirconia rotors with Kel-F end-caps. Operating conditions involved $3.2 \mu \mathrm{s} 90{ }^{\circ}{ }^{1} \mathrm{H}$ pulses and decoupling field strength of $78.1 \mathrm{kHz}$ by TPPM sequence. ${ }^{13} \mathrm{C}$ spectra were originally referenced to a glycine sample and then the chemical shifts were recalculated to the $\mathrm{Me}_{4} \mathrm{Si}$ (for the carbonyl atom $\delta$ (glycine) $=176.1 \mathrm{ppm}$ ) and ${ }^{15} \mathrm{~N}$ spectra to ${ }^{15} \mathrm{NH}_{4} \mathrm{Cl}$ and then converted to nitromethane scale using the relationship: $\delta^{15} \mathrm{~N}$ (nitromethane) $=$ $\delta^{15} \mathrm{~N}$ (ammonium chloride) - $338.1 \mathrm{ppm}$. To assign the $\mathrm{C}$-atom signals in the solid state, we run non-quaternary suppresion (NQS) experiments by conventional cross-polarization. The typical acquisition parameters for ${ }^{13} \mathrm{C}$ CPMAS were: spectral width, $40 \mathrm{kHz}$; recycle delay, $5 \mathrm{~s}$; acquisition time, $30 \mathrm{~ms}$; contact time, $2 \mathrm{~ms}$; and spin rate, $12 \mathrm{kHz}$. And for ${ }^{15} \mathrm{~N}$ CPMAS were: spectral width, $40 \mathrm{kHz}$; recycle delay, $5 \mathrm{~s}$; acquisition time, $35 \mathrm{~ms}$; contact time, $6 \mathrm{~ms}$; and spin rate, $6 \mathrm{kHz}$.

Computational details. The optimization of the structures of all compounds discussed in this paper was carried out at the hybrid B3LYP/6-31G** level with basis sets of Gaussian type 
functions using Spartan '02 Linux/Unix working on a Silicon Graphics Octane Workstation. ${ }^{13}$

$\mathrm{X}$-Ray data collection and structure refinement. Data collection for compounds $\mathbf{2}$ and $\mathbf{4}$ was carried out at room temperature on a Bruker Smart CCD diffractometer using graphitemonochromated Mo-K $\alpha$ radiation $(\lambda=0.71073 \AA)$ operating at $50 \mathrm{kV}$ and $30 \mathrm{~mA}$. In both cases, data were collected over a hemisphere of the reciprocal space by combination of three exposure sets. Each exposure of $30 \mathrm{~s}$ covered $0.3^{\circ}$ in $\omega$. The cell parameters were determined and refined by a least-squares fit of all reflections.

A summary of the fundamental crystal and refinement data are given in Table 6. The structures were solved by direct methods (SHELXS-97) and refined by full-matrix least-square procedures on $\mathrm{F}^{2}$ (SHELXL-97). ${ }^{14}$

All non-hydrogen atoms were refined anisotropically. In 4, the hexyl chain was refined anisotropically but using geometrical restrains and a variable common carbon-carbon distance. For 2 the hydrogen atoms of the methyl groups were included in calculated positions and refined riding on their carbon atoms with a common isotropic thermal parameter. The rest of hydrogens were located and included on a difference Fourier map and their coordinates and thermal parameters kept constant. For 4 the hydrogen atoms were included in calculated positions and refined riding on the respective carbon atoms with two common isotropic thermal parameters. In both compounds 2 and 4, the H3 bonded to N3 has been located and included on a difference Fourier map, their coordinates refined and a common isotropic thermal parameter fixed.

Largest peaks and holes in the final difference map were 0.199 and $-0.194,0.317$ and -0.198 e $\AA^{-3}$ for 7,10-dimethylisoalloxazine (2) and 10-hexyl-7,8-dimethylisoalloxazine (4), respectively.

CCDC-286237 and CCDC-286238 contain the supplementary crystallographic data for this paper. These data can be obtained free of charge via www.ccdc.cam.ac.uk/conts/retrieving.html (or from the Cambridge Crystallographic Data Centre, 12 Union Road, Cambridge CB2 1EZ, UK; fax: (+44) 1223-336033; or deposit@ccdc.cam.uk. 
Table 6. Crystal data and structure refinement for compounds $\mathbf{2}$ and $\mathbf{4}$

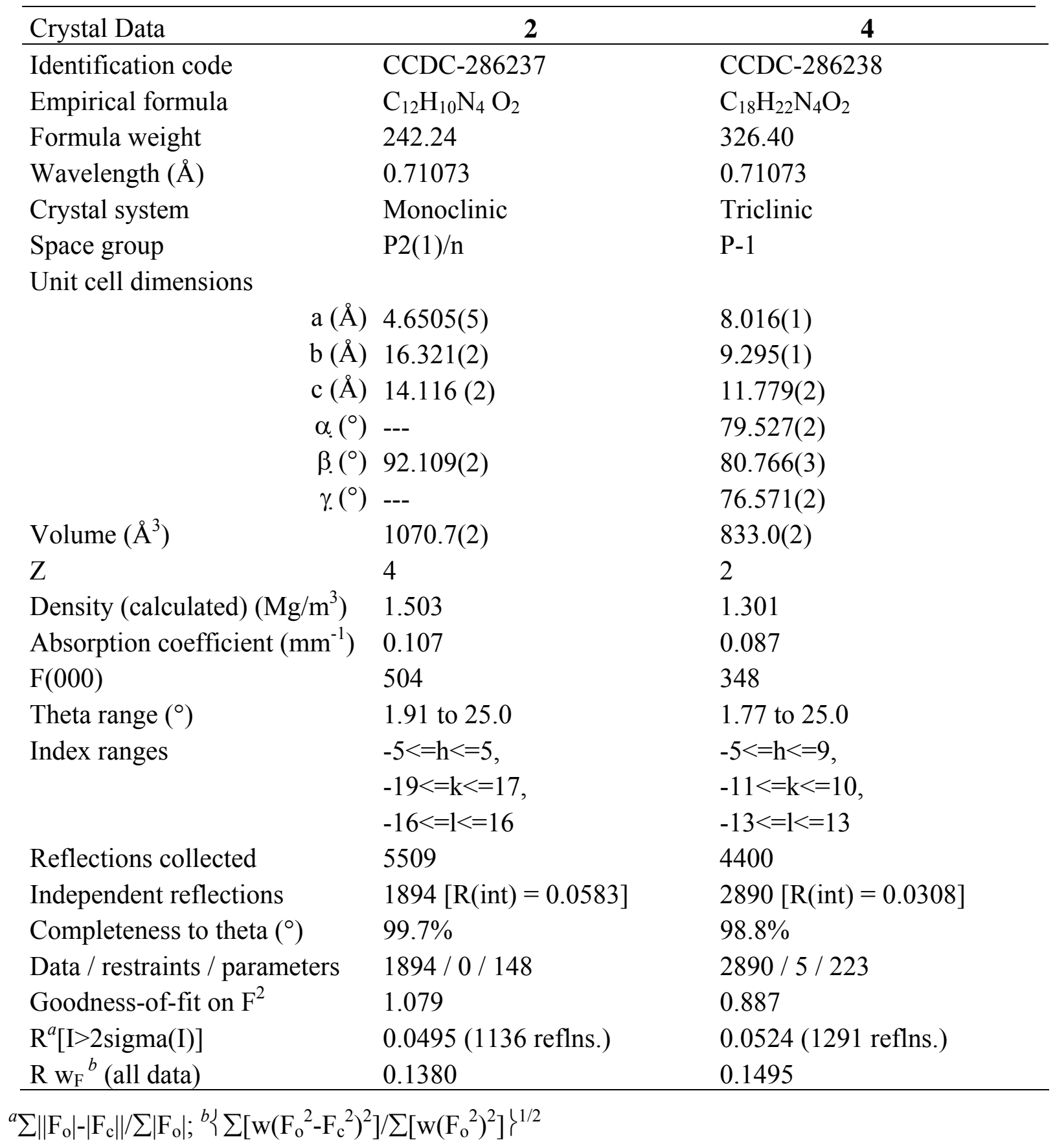

Synthesis. Pyrimidine-2,4(1H,3H)-dione derivatives $(7 \mathrm{a}-7 \mathrm{e})$. A mixture of $10 \mathrm{mmol}$ of 6 chlorouracil for $\mathbf{7 a}, \mathbf{7 b}, \mathbf{7 d}$ and $\mathbf{7 e}$ and 6-chloro-3-methyluracil for $\mathbf{7 c}$ and $20 \mathrm{mmol}$ of the corresponding anilines ( $N$-methylaniline for $7 \mathbf{a}, N$-methyl- $p$-toluidine for $\mathbf{7 b}$ and $7 \mathbf{c}, 4,5-$ dimethyl- $N$-hexylaniline for $\mathbf{7 d}$ and 3-hydroxy- $N$-hexylaniline for $\mathbf{7 e}$ ) were heated at $180{ }^{\circ} \mathrm{C}$ for 5 minutes in a Schlenk tube. The mixtures were let to cool down and diethyl ether was added. A white precipitate appeared in all cases that was washed with more diethyl ether and filtered. The 
remaining solids were crystallized in methanol to give the pyrimidinedione derivatives (7a-7e) with approximately $80 \%$ yield. ${ }^{4-6}$ The atomic numbering used for compounds $7 \mathbf{a}-7 \mathbf{e}$ in the NMR assignments is depicted below.

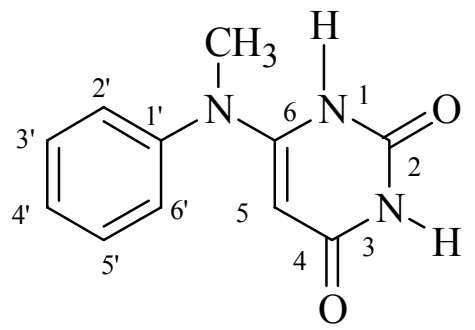

6-[Methyl(phenyl)amino]pyrimidine-2,4(1H,3H)-dione (7a). M.p. $302^{\circ} \mathrm{C} . \delta_{\mathrm{H}}(400.13 \mathrm{MHz}$; DMSO-d 6 ) $10.42\left(1 \mathrm{H}\right.$, br s, N(3)H), $10.25(1 \mathrm{H}, \mathrm{br} \mathrm{s}, \mathrm{N}(1) \mathrm{H}), 7.44\left(2 \mathrm{H}, \mathrm{t}, \mathrm{C}\left(3^{\prime}, 5^{\prime}\right) \mathrm{H},{ }^{3} J=7.5 \mathrm{~Hz}\right)$, $7.31\left(1 \mathrm{H}, \mathrm{t}, \mathrm{C}\left(4^{\prime}\right) \mathrm{H},{ }^{3} J=7.5 \mathrm{~Hz}\right), 7.27\left(2 \mathrm{H}, \mathrm{d}, \mathrm{C}\left(2^{\prime}, 6^{\prime}\right) \mathrm{H},{ }^{3} J=8.2 \mathrm{~Hz}\right), 4.25(1 \mathrm{H}, \mathrm{s}, \mathrm{C}(5) \mathrm{H}), 3.26$ $\left(3 \mathrm{H}, \mathrm{s},\left(\mathrm{N}\left(\mathrm{CH}_{3}\right)\right) . \delta_{\mathrm{C}}\left(100.63 \mathrm{MHz}, \mathrm{DMSO}-\mathrm{d}_{6}\right): \delta 163.8(\mathrm{C}(4)), 155.1(\mathrm{C}(6)), 151.3(\mathrm{C}(2)), 144.2\right.$ $\left(\mathrm{C}\left(1^{\prime}\right)\right), 129.9\left(\mathrm{C}\left(3^{\prime}, 5^{\prime}\right)\right), 126.5\left(\mathrm{C}\left(2^{\prime}, 6^{\prime}\right)\right), 116.6\left(\mathrm{C}\left(4^{\prime}\right)\right), 78.4(\mathrm{C}(5)), 39.7\left(\mathrm{~N}\left(\mathrm{CH}_{3}\right)\right)$.

6-[Methyl(4-methylphenyl)amino]pyrimidine-2,4(1H,3H)-dione (7b). M.p. $315^{\circ} \mathrm{C}$ (dec.).

$\left.\delta_{\mathrm{H}}(400.13 \mathrm{MHz} \text {; DMSO-d })_{6}\right) 10.36(1 \mathrm{H}$, br s, N(3)H), $10.13(1 \mathrm{H}$, br s, N(1)H), $7.24(2 \mathrm{H}, \mathrm{d}$, $\left.\mathrm{C}\left(3^{\prime}, 5^{\prime}\right) \mathrm{H},{ }^{3} J=8.5 \mathrm{~Hz}\right), 7.13\left(2 \mathrm{H}, \mathrm{d}, \mathrm{C}\left(2^{\prime}, 6^{\prime}\right) \mathrm{H},{ }^{3} J=8.5 \mathrm{~Hz}\right), 4.20(1 \mathrm{H}, \mathrm{s}, \mathrm{C}(5) \mathrm{H}), 3.20(3 \mathrm{H}, \mathrm{s}$, $\left.\mathrm{N}\left(\mathrm{CH}_{3}\right)\right), 2.31\left(3 \mathrm{H}, \mathrm{s}, \mathrm{C}\left(4^{\prime}\right) \mathrm{CH}_{3}\right) . \delta_{\mathrm{C}}\left(100.63 \mathrm{MHz} ; \mathrm{DMSO}-\mathrm{d}_{6}\right) 163.7(\mathrm{C}(4)), 155.1(\mathrm{C}(6))$, 151.2(C(2)), $141.6\left(\mathrm{C}\left(1^{\prime}\right)\right), 130.3\left(\mathrm{C}\left(4^{\prime}\right)\right), 136.6\left(\mathrm{C}\left(3^{\prime}, 5^{\prime}\right)\right), 126.5\left(\mathrm{C}\left(2^{\prime}, 6^{\prime}\right)\right), 77.8(\mathrm{C}(5)), 39.7$ $\left(\mathrm{N}\left(\mathrm{CH}_{3}\right)\right), 20.7\left(\mathrm{C}\left(4^{\prime}\right) \mathrm{CH}_{3}\right)$.

3-Methyl-6-[methyl(4-methylphenyl)amino]pyrimidine-2,4(1H,3H)-dione (7c). M.p. $184{ }^{\circ} \mathrm{C}$. $\delta_{\mathrm{H}}(400.13 \mathrm{MHz}$; DMSO-d 6$) 10.45\left(1 \mathrm{H}\right.$, br s, N(1)H), $7.24\left(2 \mathrm{H}, \mathrm{d}, \mathrm{C}\left(3^{\prime}, 5^{\prime}\right) \mathrm{H},{ }^{3} J=8.5 \mathrm{~Hz}\right), 7.14$ $\left(2 \mathrm{H}, \mathrm{d}, \mathrm{C}\left(2^{\prime}, 6^{\prime}\right) \mathrm{H},{ }^{3} J=8.5 \mathrm{~Hz}\right), 4.40(1 \mathrm{H}, \mathrm{s}, \mathrm{C}(5) \mathrm{H}), 3.21\left(3 \mathrm{H}, \mathrm{s}, \mathrm{N}\left(\mathrm{CH}_{3}\right)\right), 3.04\left(3 \mathrm{H}, \mathrm{s}, \mathrm{N}(3) \mathrm{CH}_{3}\right)$, $2.31\left(3 \mathrm{H}, \mathrm{s}, \mathrm{C}\left(4^{\prime}\right) \mathrm{CH}_{3}\right) . \delta_{\mathrm{C}}(100.63 \mathrm{MHz}$; DMSO-d 6$) 162.8(\mathrm{C}(4)), 153.5(\mathrm{C}(6)), 151.4(\mathrm{C}(2))$, $141.3\left(\mathrm{C}\left(1^{\prime}\right)\right), 136.5\left(\mathrm{C}\left(3^{\prime}, 5^{\prime}\right)\right), 130.4\left(\mathrm{C}\left(4^{\prime}\right)\right), 126.6\left(\mathrm{C}\left(2^{\prime}, 6^{\prime}\right)\right), 78.0(\mathrm{C}(5)), 39.7\left(\mathrm{~N}^{\prime}\left(\mathrm{CH}_{3}\right)\right), 26.1$ $\left(\mathrm{N}(3) \mathrm{CH}_{3}\right), 20.7\left(\mathrm{C}\left(4^{\prime}\right) \mathrm{CH}_{3}\right)$.

6-[(3,4-Dimethylphenyl)(hexyl)amino]pyrimidine-2,4(1H,3H)-dione (7d). M.p. $228{ }^{\circ} \mathrm{C}$. $\delta_{\mathrm{H}}\left(400.13 \mathrm{MHz} ; \mathrm{CDCl}_{3}\right) 8.65(1 \mathrm{H}$, br s, $\mathrm{N}(3) \mathrm{H}), 7.22\left(1 \mathrm{H}, \mathrm{d}, \mathrm{C}\left(5^{\prime}\right) \mathrm{H},{ }^{3} J=7.8 \mathrm{~Hz}\right), 7.08(1 \mathrm{H}, \mathrm{br}$ s, $\mathrm{N}(1) \mathrm{H}), 6.93\left(1 \mathrm{H}, \mathrm{s}, \mathrm{C}\left(2^{\prime}\right) \mathrm{H}\right), 6.91\left(1 \mathrm{H}, \mathrm{d}, \mathrm{C}\left(6^{\prime}\right) \mathrm{H},{ }^{3} J=7.8 \mathrm{~Hz}\right), 4.89(1 \mathrm{H}, \mathrm{s}, \mathrm{C}(5) \mathrm{H}), 3.48(2 \mathrm{H}$, t, $\left.\mathrm{NCH}_{2}-\left(\mathrm{CH}_{2}\right)_{4} \mathrm{CH}_{3},{ }^{3} J=8.0 \mathrm{~Hz}\right), 1.64$ and $1.25\left(8 \mathrm{H}, \mathrm{m}, \mathrm{NCH}_{2}-\left(\mathrm{CH}_{2}\right)_{4} \mathrm{CH}_{3}\right), 2.28,(3 \mathrm{H}, \mathrm{s}$, $\left.\mathrm{C}\left(3^{\prime}\right) \mathrm{CH}_{3}\right), 2.29\left(3 \mathrm{H}, \mathrm{s}, \mathrm{C}\left(4^{\prime}\right) \mathrm{CH}_{3}\right), 0.86\left(3 \mathrm{H}, \mathrm{t}, \mathrm{NCH}_{2}-\left(\mathrm{CH}_{2}\right)_{4} \mathrm{CH}_{3},{ }^{3} J=6.3 \mathrm{~Hz}\right) . \delta_{\mathrm{C}}(100.63 \mathrm{MHz}$; $\left.\mathrm{CDCl}_{3}\right) 164.9(\mathrm{C}(4)), 152.7(\mathrm{C}(6)), 150.3(\mathrm{C}(2)), 139.6\left(\mathrm{C}\left(1^{\prime}\right)\right), 138.2\left(\mathrm{C}\left(3^{\prime}\right)\right), 137.3\left(\mathrm{C}\left(4^{\prime}\right)\right)$, 131.7(C(5')), $129.0\left(\mathrm{C}\left(2^{\prime}\right)\right), \quad 125.4 \quad\left(\mathrm{C}\left(6^{\prime}\right)\right), \quad 75.7 \quad(\mathrm{C}(5)), \quad 52.6 \quad\left(\mathrm{NCH}_{2}\left(\mathrm{CH}_{2}\right)_{4} \mathrm{CH}_{3}\right), \quad 31.4$

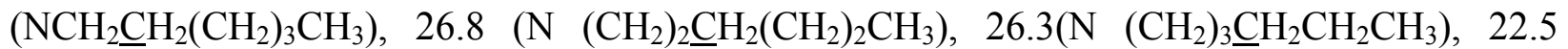
$\left.\left(\mathrm{N}\left(\mathrm{CH}_{2}\right)_{4} \mathrm{CH}_{2} \mathrm{CH}_{3}\right), 19.8\left(\mathrm{C}\left(4^{\prime}\right) \mathrm{CH}_{3}\right), 19.4\left(\mathrm{C}^{\prime} 3^{\prime}\right) \mathrm{CH}_{3}\right), 13.9\left(\mathrm{~N}_{(}\left(\mathrm{CH}_{2}\right)_{5} \underline{\mathrm{CH}_{3}}\right)$.

6-[Hexyl(3-hydroxyphenyl)-amino]pyrimidine 2,4(1H,3H)-dione (7e). M.p. $235^{\circ} \mathrm{C}$.

$\left.\delta_{\mathrm{H}}(400.13 \mathrm{MHz} \text {; DMSO-d })_{6}\right) 11.41(1 \mathrm{H}$, br s, N(1)H), $11.17(1 \mathrm{H}$, br s, N(3)H), $10.73(1 \mathrm{H}$, br s, $\left.\mathrm{OHC}\left(3^{\prime}\right)\right), 8.27\left(1 \mathrm{H}, \mathrm{d}, \mathrm{C}\left(5^{\prime}\right) \mathrm{H},{ }^{3} J=8.1 \mathrm{~Hz}\right), 7.77\left(1 \mathrm{H}, \mathrm{d}, \mathrm{C}\left(6^{\prime}\right) \mathrm{H},{ }^{3} J=8.1 \mathrm{~Hz}\right), 7.68(1 \mathrm{H}, \mathrm{d}$, 
$\left.\mathrm{C}\left(4^{\prime}\right) \mathrm{H},{ }^{3} J=8.1 \mathrm{~Hz}\right), 7.63\left(1 \mathrm{H}, \mathrm{s}, \mathrm{C}\left(2^{\prime}\right) \mathrm{H}\right), 5.22(\mathrm{~s}, 1 \mathrm{H}, \mathrm{C}(5) \mathrm{H}), 4.60\left(2 \mathrm{H}, \mathrm{t}, \mathrm{NCH}_{2}\left(\mathrm{CH}_{2}\right)_{4} \mathrm{CH}_{3},{ }^{3} J=\right.$ $7.3 \mathrm{~Hz}), 2.25\left(\mathrm{~m}, 8 \mathrm{H}, \mathrm{NCH}_{2}\left(\mathrm{CH}_{2}\right)_{4} \mathrm{CH}_{3}\right), 1.86\left(3 \mathrm{H}, \mathrm{t}, \mathrm{NCH}_{2}\left(\mathrm{CH}_{2}\right)_{4} \mathrm{CH}_{3},{ }^{3} J=6.2 \mathrm{~Hz}\right)$,

$\delta_{\mathrm{C}}(100.63 \mathrm{MHz}$; DMSO-d 6$) 163.6(\mathrm{C}(4)), 158.4\left(\mathrm{C}\left(3^{\prime}\right)\right), 154.1$ (C(6)), 151.3 (C(2)), 143.2 $\left(\mathrm{C}\left(1^{\prime}\right)\right), 130.5\left(\mathrm{C}\left(5^{\prime}\right)\right), 117.8\left(\mathrm{C}\left(4^{\prime}\right)\right), 114.6\left(\mathrm{C}\left(6^{\prime}\right)\right), 77.6\left(\mathrm{C}(5), 50.8\left(\mathrm{NCH}_{2}\left(\mathrm{CH}_{2}\right)_{4} \mathrm{CH}_{3}\right), 31.0\right.$ $\left(\mathrm{NCH}_{2} \underline{\mathrm{CH}}_{2}\left(\mathrm{CH}_{2}\right)_{3} \mathrm{CH}_{3}\right), 27.3\left(\mathrm{~N}\left(\mathrm{CH}_{2}\right)_{2} \underline{\mathrm{CH}}_{2}\left(\mathrm{CH}_{2}\right)_{2} \mathrm{CH}_{3}\right), 25.5\left(\mathrm{~N}\left(\mathrm{CH}_{2}\right)_{3} \underline{\mathrm{CH}}_{2} \mathrm{CH}_{2} \mathrm{CH}_{3}\right), 22.0(\mathrm{~N}$ $\left.\left(\mathrm{CH}_{2}\right)_{4} \underline{\mathrm{CH}}_{2} \mathrm{CH}_{3}\right), 13.8\left(\mathrm{~N}\left(\mathrm{CH}_{2}\right)_{5} \underline{\mathrm{CH}}_{3}\right)$.

Isoalloxazine-5-oxides (8a-8e). $0.01 \mathrm{Mmol}$ of 7a-7e were dissolved in $20 \mathrm{~mL}$ of acetic acid and to the solution sodium nitrite was added $(3.5 \mathrm{~g}, 0.05 \mathrm{mmol})$ all at once. The mixture was stirred at room temperature, then water $(50 \mathrm{~mL})$ was added and allowed to stand for another 2-3 hours. The crude compounds were collected by filtration, washed with water several times and dried. The solids were crystallized from acetic acid to afford orange-reddish products with a yield of approximately $85 \%$ in all five cases. All compounds melted above $300{ }^{\circ} \mathrm{C}$ with decomposition. ${ }^{4-6}$ 10-Mehylbenzo[g]pteridine-2,4(3H,10H)-dione-5-oxide (8a). $\delta_{\mathrm{H}}\left(400.13 \mathrm{MHz}\right.$; DMSO- $\left.\mathrm{d}_{6}\right)$ $11.10\left(1 \mathrm{H}\right.$, br s, N(3)H), $\left.8.30\left(2 \mathrm{H}, \mathrm{d}, \mathrm{C}(6) \mathrm{H},{ }^{3} \mathrm{~J}=8.3 \mathrm{~Hz}\right), 7.95(1 \mathrm{H}, \mathrm{m}, \mathrm{C}(8) \mathrm{H})\right), 7.94(1 \mathrm{H}, \mathrm{m}$, $\mathrm{C}(9) \mathrm{H}), 7.57(1 \mathrm{H}, \mathrm{m}, \mathrm{C}(7) \mathrm{H}) 3.89\left(3 \mathrm{H}, \mathrm{s}, \mathrm{N}(10) \mathrm{CH}_{3}\right) . \delta_{\mathrm{C}}(100.63 \mathrm{MHz}$; DMSO-d 6$) 155.5(\mathrm{C}(2))$, 159.7 (C(4)), 150.9(C(10a)), 138.6 (C(9a)), 136.2(C(8)), 133.3 (C(4a)), 127.0 (C(5a)), 131.6 $(\mathrm{C}(7)), 126.6(\mathrm{C}(6)), 116.6(\mathrm{C}(9)), 31.9\left(\mathrm{~N}(10) \mathrm{CH}_{3}\right)$.

7,10-Dimethylbenzo[g]pteridine-2,4(3H,10H)-dione-5-oxide (8b). $\delta_{\mathrm{H}}(400.13 \mathrm{MHz}$; DMSO$\left.\mathrm{d}_{6}\right) 11.0\left(1 \mathrm{H}\right.$, br s, N(3)H), $8.12(1 \mathrm{H}, \mathrm{s}, \mathrm{C}(6) \mathrm{H}), 7.87\left(1 \mathrm{H}, \mathrm{d}, \mathrm{C}(8) \mathrm{H},{ }^{3} J=8.5 \mathrm{~Hz}\right), 7.79(1 \mathrm{H}, \mathrm{d}$, $\left.\mathrm{C}(9) \mathrm{H},{ }^{3} \mathrm{~J}=8.5 \mathrm{~Hz}\right), 3.89\left(3 \mathrm{H}, \mathrm{s}, \mathrm{N}(10) \mathrm{CH}_{3}\right), 3.30\left(3 \mathrm{H}, \mathrm{s}, \mathrm{C}(7) \mathrm{CH}_{3}\right) . \delta_{\mathrm{C}}(100.63 \mathrm{MHz}$; DMSO-d 6$)$ $156.0(\mathrm{C}(4)), 154.0(\mathrm{C}(2)), 151.4(\mathrm{C}(10 \mathrm{a})), 136.8(\mathrm{C}(8)), 136.1(\mathrm{C}(7)), 34.0(\mathrm{C}(9 \mathrm{a})), 132.6(\mathrm{C}(4 \mathrm{a}))$, 130.8(C(5a)), 119.6(C(6)), 117.5(C(9)), $32.0\left(\mathrm{~N}(10) \mathrm{CH}_{3}\right), 20.6\left(\mathrm{C}(7) \mathrm{CH}_{3}\right)$.

3,7,10-Trimethylbenzo[g]pteridine-2,4(3H,10H)-dione-5-oxide (8c). $\delta_{\mathrm{H}}(400.13 \mathrm{MHz}$; DMSO$\left.\mathrm{d}_{6}\right) 8.15(1 \mathrm{H}, \mathrm{s}, \mathrm{C}(6) \mathrm{H}), 7.90\left(1 \mathrm{H}, \mathrm{d}, \mathrm{C}(8) \mathrm{H},{ }^{3} J=8.5 \mathrm{~Hz}\right), 7.81\left(1 \mathrm{H}, \mathrm{d}, \mathrm{C}(9) \mathrm{H},{ }^{3} J=8.5 \mathrm{~Hz}\right), 3.91$ $\left(3 \mathrm{H}, \mathrm{s}, \mathrm{N}(10) \mathrm{CH}_{3}\right), 3.19\left(3 \mathrm{H}, \mathrm{s}, \mathrm{N}(3) \mathrm{CH}_{3}\right), 2.52\left(3 \mathrm{H}, \mathrm{s}, \mathrm{C}(7) \mathrm{CH}_{3}\right) . \delta_{\mathrm{C}}(100.63 \mathrm{MHz}$; DMSO-d 6$)$ 156.0 (C(4)), $154.0(\mathrm{C}(2)), 151.4(\mathrm{C}(10 \mathrm{a})), 136.7$ (C(8)), 136.1 (C(7)), 134.0 (C(9a)), 132.6 $(\mathrm{C}(4 \mathrm{a})), 130.8(\mathrm{C}(5 \mathrm{a})), 119.7(\mathrm{C}(6)), 117.5(\mathrm{C}(9)), 31.8\left(\mathrm{~N}(10) \mathrm{CH}_{3}\right), 27.6\left(\mathrm{~N}(3) \mathrm{CH}_{3}\right), 20.5$ $\left(\mathrm{C}(7) \mathrm{CH}_{3}\right)$.

10-Hexyl-7,8-dimethylbenzo[g]pteridine-2,4(3H,10H)-dione-5-oxide (8d). $\delta_{\mathrm{H}}(400.13 \mathrm{MHz}$ $\left.\mathrm{CDCl}_{3}\right) 8.06(1 \mathrm{H}, \mathrm{s}, \mathrm{N}(3) \mathrm{H}), 7.38(1 \mathrm{H}, \mathrm{s}, \mathrm{C}(9) \mathrm{H}), 7.26(1 \mathrm{H}, \mathrm{s}, \mathrm{C}(6) \mathrm{H}), 4.64(2 \mathrm{H}, \mathrm{t}$, $\left.\mathrm{N}(10) \mathrm{CH}_{2}\left(\mathrm{CH}_{2}\right)_{4} \mathrm{CH}_{3}\right), 2.56\left(3 \mathrm{H}, \mathrm{s}, \mathrm{C}(7) \mathrm{CH}_{3}\right), 2.45 \quad\left(3 \mathrm{H}, \mathrm{s}, \mathrm{C}(8) \mathrm{CH}_{3}\right), 1.85 \quad(2 \mathrm{H}, \mathrm{m}$, $\left.\mathrm{N}(10) \mathrm{CH}_{2} \underline{\mathrm{C}}_{2}\left(\mathrm{CH}_{2}\right)_{3} \mathrm{CH}_{3}\right), \quad 1.53\left(2 \mathrm{H}, \quad \mathrm{m}, \quad \mathrm{N}(10)\left(\mathrm{CH}_{2}\right)_{2} \mathrm{C}_{2}\left(\mathrm{CH}_{2}\right)_{2} \mathrm{CH}_{3}\right), \quad 1.36 \quad$ (4H, m, $\left.\mathrm{N}(10)\left(\mathrm{CH}_{2}\right)_{3}\left(\mathrm{CH}_{2}\right)_{2} \mathrm{CH}_{3}\right), 0.91\left(3 \mathrm{H}, \mathrm{t}, \mathrm{N}(10)\left(\mathrm{CH}_{2}\right)_{5} \mathrm{CH}_{3}\right) . \delta_{\mathrm{C}}\left(100.62 \mathrm{MHz} ; \mathrm{CDCl}_{3}\right) 156.2(\mathrm{C}(4))$, 154.4 (C(2)), 152.7 (C(10a)), 147.8 (C(9a)), 144.5 (C(4a)), 136.9 (C(7)), 133.3 (C(5a)), 132.2 $(\mathrm{C}(8)), 121.6(\mathrm{C}(6)), 116.3(\mathrm{C}(9)), 45.1\left(\mathrm{~N}(10) \underline{\mathrm{CH}}_{2}\left(\mathrm{CH}_{2}\right)_{4} \mathrm{CH}_{3}\right), 31.4\left(\mathrm{~N}(10) \mathrm{CH}_{2}-\underline{\mathrm{CH}}_{2}\left(\mathrm{CH}_{2}\right)_{3} \mathrm{CH}_{3}\right)$, $27.2\left(\mathrm{~N}(10)\left(\mathrm{CH}_{2}\right)_{2}\left(\underline{\mathrm{CH}}_{2}\right)_{2} \mathrm{CH}_{2} \mathrm{CH}_{3}\right), \quad 26.4 \quad\left(\mathrm{~N}(10)\left(\mathrm{CH}_{2}\right)_{4} \underline{\mathrm{CH}}_{2} \mathrm{CH}_{3}\right), \quad 22.5\left(\mathrm{C}(8) \mathrm{CH}_{3}\right), \quad 21.2$

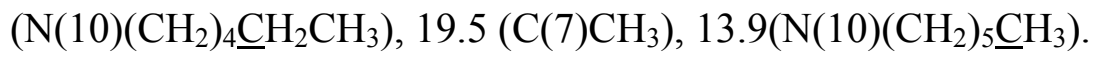

10-Hexyl-8-hydroxybenzo[g]pteridine-2,4(3H,10H)-dione-5-oxide (8e). $\delta_{\mathrm{H}}(400.13 \mathrm{MHz}$; DMSO-d $\left._{6}\right) 11.15\left(1 \mathrm{H}\right.$, br s, N(3)H), $7.94\left(1 \mathrm{H}, \mathrm{d}, \mathrm{C}(6) \mathrm{H},{ }^{3} J=9.0 \mathrm{~Hz}\right), 7.11\left(1 \mathrm{H}, \mathrm{d}, \mathrm{C}(7) \mathrm{H},{ }^{3} J=\right.$ $9.0 \mathrm{~Hz}), 7.04(1 \mathrm{H}, \mathrm{s}, \mathrm{C}(9) \mathrm{H}), 4.45\left(2 \mathrm{H}, \mathrm{t}, \mathrm{N}(10) \mathrm{C}_{2}\left(\mathrm{CH}_{2}\right)_{4} \mathrm{CH}_{3},{ }^{3} J=7.3 \mathrm{~Hz}\right), 1.68(2 \mathrm{H}, \mathrm{m}$, 
$\left.\mathrm{N}(10) \mathrm{CH}_{2} \underline{\mathrm{CH}}_{2}\left(\mathrm{CH}_{2}\right)_{3} \mathrm{CH}_{3}\right), \quad 1.43 \quad\left(2 \mathrm{H}, \quad \mathrm{m}, \quad \mathrm{N}(10)\left(\mathrm{CH}_{2}\right)_{2} \mathrm{CH}_{2}\left(\mathrm{CH}_{2}\right)_{2} \mathrm{CH}_{3}\right), \quad 1.31 \quad$ (4H, m, $\left.\mathrm{N}(10)\left(\mathrm{CH}_{2}\right)_{3}\left(\mathrm{CH}_{2}\right)_{2} \mathrm{CH}_{3}\right), 0.87\left(3 \mathrm{H}, \mathrm{t}, \mathrm{N}(10)\left(\mathrm{CH}_{2}\right)_{5} \mathrm{CH}_{3},{ }^{3} \mathrm{~J}=7.0 \mathrm{~Hz}\right)$.

Isoalloxazines (1-5). To a solution of sodium dithionate $(5.2 \mathrm{~g}, 0.03 \mathrm{~mol})$ in $10 \mathrm{~mL}$ of water was added $0.01 \mathrm{~mol}$ of the corresponding $N$-oxide (8a-8e) and the mixtures were stirred for 2-3 hours at room temperature. To the reaction mixtures were then added $2 \mathrm{~mL}$ of a $30 \%$ hydrogen peroxide solution and allowed to stand overnight. The dark yellow solids were filtered, washed with water and crystallized from acetic acid (compounds 1-3), ethanol (compound 4) and $N, N$ dimethylformamide (compound 5) to yield isoalloxazines with approximately $80 \%$ yield.

10-Methylisoalloxazine (1). M. p. $352{ }^{\circ} \mathrm{C} .{ }^{4} \delta_{\mathrm{H}}\left(400.13 \mathrm{MHz}\right.$; DMSO-d $\left.{ }_{6}\right) 11.3(1 \mathrm{H}$, br s, N(3)H), $8.12\left(\mathrm{~d}, 1 \mathrm{H}, \mathrm{C}(6) \mathrm{H},{ }^{3} \mathrm{~J}=8.5 \mathrm{~Hz}\right), 7.94(2 \mathrm{H}, \mathrm{m}, \mathrm{C}(8) \mathrm{H}, \mathrm{C}(9) \mathrm{H}), 7.64\left(1 \mathrm{H}, \mathrm{dd}, \mathrm{C}(7) \mathrm{H},{ }^{3} \mathrm{~J}=8.5 \mathrm{~Hz},{ }^{4} J\right.$ $=2.2 \mathrm{~Hz}), 3.96\left(3 \mathrm{H}, \mathrm{s}, \mathrm{N}(10) \mathrm{CH}_{3}\right)$.

7,10-Dimethylisoalloxazine (2). M. p. $335{ }^{\circ} \mathrm{C} .{ }^{5} \delta_{\mathrm{H}}(400.13 \mathrm{MHz} \text {; DMSO-d })_{6} 11.30(1 \mathrm{H}, \mathrm{s}$, $\mathrm{N}(3) \mathrm{H}), 7.92(1 \mathrm{H}, \mathrm{s}, \mathrm{C}(6) \mathrm{H}), 7.84\left(1 \mathrm{H}, \mathrm{d}, \mathrm{C}(8) \mathrm{H},{ }^{3} J=8.5 \mathrm{~Hz}\right), 7.78\left(1 \mathrm{H}, \mathrm{d}, \mathrm{C}(9) \mathrm{H},{ }^{3} J=8.5 \mathrm{~Hz}\right)$, $3.95\left(3 \mathrm{H}, \mathrm{s}, \mathrm{N}(10) \mathrm{CH}_{3}\right), 2.52\left(3 \mathrm{H}, \mathrm{s}, \mathrm{C}(7) \mathrm{CH}_{3}\right)$.

3,7,10-Trimethylisoalloxazine (3). M. p. $395{ }^{\circ} \mathrm{C} .{ }^{6} \delta_{\mathrm{H}}\left(400.13 \mathrm{MHz}\right.$; DMSO-d $\left.\mathrm{d}_{6}\right) 7.96(1 \mathrm{H}, \mathrm{s}$, $\mathrm{C}(6) \mathrm{H}), 7.87(1 \mathrm{H}, \mathrm{d}, \mathrm{C}(9) \mathrm{H} J=8.8 \mathrm{~Hz}), 7.80\left(1 \mathrm{H}, \mathrm{dd}, \mathrm{C}(8) \mathrm{H}^{3} J=8.8 \mathrm{~Hz},{ }^{4} J=2.0 \mathrm{~Hz}\right), 3.97(3 \mathrm{H}$, s, $\left.\mathrm{N}(10) \mathrm{CH}_{3}\right), 3.23\left(3 \mathrm{H}, \mathrm{s}, \mathrm{N}(3) \mathrm{CH}_{3}\right), 2.52\left(3 \mathrm{H}, \mathrm{s}, \mathrm{C}(7) \mathrm{CH}_{3}\right)$.

10-Hexyl-7,8-dimethylisoalloxazine (4). M. p. $267{ }^{\circ} \mathrm{C}$. Exact mass calcd. for $\mathrm{C}_{18} \mathrm{H}_{22} \mathrm{~N}_{4} \mathrm{O}_{2}$ : 326.17428; found 326.1. $\delta_{\mathrm{H}}\left(400.13 \mathrm{MHz}, \mathrm{CDCl}_{3}\right) 8.46(1 \mathrm{H}$, br s, $\mathrm{N}(3) \mathrm{H}), 8.06(1 \mathrm{H}, \mathrm{s}, \mathrm{C}(6) \mathrm{H})$, $7.40(1 \mathrm{H}, \mathrm{s}, \mathrm{C}(9) \mathrm{H}), 4.70\left(2 \mathrm{H}\right.$, br m, N(10) $\left.\mathrm{CH}_{2}\left(\mathrm{CH}_{2}\right)_{4} \mathrm{CH}_{3}\right), 2.57\left(3 \mathrm{H}, \mathrm{s}, \mathrm{C}(7) \mathrm{CH}_{3}\right), 2.46(3 \mathrm{H}, \mathrm{s}$, $\mathrm{C}(8)\left(\mathrm{CH}_{3}\right), 1.86\left(2 \mathrm{H}, \mathrm{m}, \mathrm{N}(10) \mathrm{CH}_{2} \underline{\mathrm{C}}_{2}\left(\mathrm{CH}_{2}\right)_{3} \mathrm{CH}_{3}\right), 1.53\left(2 \mathrm{H}, \mathrm{m}, \mathrm{N}(10)\left(\mathrm{CH}_{2}\right)_{2} \mathrm{C}_{2}\left(\mathrm{CH}_{2}\right)_{2} \mathrm{CH}_{3}\right)$, $1.37\left(4 \mathrm{H}, \mathrm{m}, \mathrm{N}(10)\left(\mathrm{CH}_{2}\right)_{3}\left(\mathrm{CH}_{2}\right)_{2} \mathrm{CH}_{3}\right), 0.92\left(3 \mathrm{H}, \mathrm{t}, \mathrm{N}(10)\left(\mathrm{CH}_{2}\right)_{5} \mathrm{CH}_{3},{ }^{3} J=7.0 \mathrm{~Hz}\right) . \delta_{\mathrm{H}}(400.13$ MHz; DMSO-d $611.20(1 \mathrm{H}$, br s, N(3)H), $7.78(1 \mathrm{H}, \mathrm{s}, \mathrm{C}(6) \mathrm{H}), 7.69(1 \mathrm{H}, \mathrm{s}, \mathrm{C}(9) \mathrm{H}, 4.48(2 \mathrm{H}$, br $\left.\mathrm{m}, \mathrm{N}(10) \mathrm{CH}_{2}\left(\mathrm{CH}_{2}\right)_{4} \mathrm{CH}_{3}\right), 2.41\left(3 \mathrm{H}, \mathrm{s}, \mathrm{C}(7) \mathrm{CH}_{3}\right), 2.30\left(3 \mathrm{H}, \mathrm{s}, \mathrm{C}(8)\left(\mathrm{CH}_{3}\right), 1.68(2 \mathrm{H}, \mathrm{m}\right.$, $\left.\mathrm{N}(10) \mathrm{CH}_{2} \underline{\mathrm{C}}_{2}\left(\mathrm{CH}_{2}\right)_{3} \mathrm{CH}_{3}\right), 1.43\left(2 \mathrm{H}, \mathrm{m}, \mathrm{N}(10)\left(\mathrm{CH}_{2}\right)_{2} \mathrm{CH}_{2}\left(\mathrm{CH}_{2}\right)_{2} \mathrm{CH}_{3}\right), 1.27$ (4H, m, N(10 )$\left.\left(\mathrm{CH}_{2}\right)_{3}\left(\mathrm{CH}_{2}\right)_{2} \mathrm{CH}_{3}\right), 0.85\left(3 \mathrm{H}, \mathrm{t}, \mathrm{N}(10)\left(\mathrm{CH}_{2}\right)_{5} \mathrm{CH}_{3},{ }^{3} \mathrm{~J}=7.0 \mathrm{~Hz}\right)$.

10-Hexyl-8-hydroxyisoalloxazine (5). M. p. $338{ }^{\circ} \mathrm{C}$. Exact mass calcd. for $\mathrm{C}_{16} \mathrm{H}_{18} \mathrm{~N}_{4} \mathrm{O}_{3}$ : 314.13789; found 314.2. $\delta_{\mathrm{H}}(400.13 \mathrm{MHz} \text {; DMSO-d })_{6} 11.40(1 \mathrm{H}$, br s, C(8)OH) $11.20(1 \mathrm{H}$, br s, $\mathrm{N}(3) \mathrm{H}), 7.96\left(1 \mathrm{H}, \mathrm{d}, \mathrm{C}(7) \mathrm{H},{ }^{3} J=9.0 \mathrm{~Hz}\right), 7.13\left(1 \mathrm{H}, \mathrm{d}, \mathrm{C}(6) \mathrm{H},{ }^{3} J=9.0 \mathrm{~Hz}\right), 7.07(1 \mathrm{H}, \mathrm{s}, \mathrm{C}(9) \mathrm{H})$, $4.45\left(2 \mathrm{H}, \mathrm{t}, \mathrm{N}(10)-\underline{\mathrm{C}}_{2}\left(\mathrm{CH}_{2}\right)_{4} \mathrm{CH}_{3},{ }^{3} \mathrm{~J}=7.2 \mathrm{~Hz}\right), 1.69\left(2 \mathrm{H}, \mathrm{m}, \mathrm{N}(10) \mathrm{CH}_{2} \mathrm{CH}_{2}\left(\mathrm{CH}_{2}\right)_{3} \mathrm{CH}_{3}\right), 1.43$ $\left(2 \mathrm{H}, \mathrm{m}, \mathrm{N}(10)\left(\mathrm{CH}_{2}\right)_{2} \mathrm{C}_{2}\left(\mathrm{CH}_{2}\right)_{2} \mathrm{CH}_{3}\right), 1.31\left(4 \mathrm{H}, \mathrm{m}, \mathrm{N}(10)\left(\mathrm{CH}_{2}\right)_{3}\left(\mathrm{C}_{2}\right)_{2} \mathrm{CH}_{3}\right), 0.87$ (3H, t, $\left.\mathrm{N}(10)\left(\mathrm{CH}_{2}\right)_{5} \underline{\mathrm{CH}}_{3},{ }^{3} \mathrm{~J}=7.0 \mathrm{~Hz}\right)$.

\section{Acknowledgements}

This work has been financed by the Ministerio de Ciencia y Tecnología of Spain (BQU200300976). One of us (M.A.F.) thanks the Ministerio de Educación y Ciencia of Spain for a "Ramon y Cajal" contract. 


\section{References}

1. Reid, G.A. Flavins and Other Flavoproteins, Proceedings of the Fourteenth International Symposium, Chapman, S.; Perham, R.; Scrutton, N. Eds. Rudolf Weber: Berlin, 2002.

2. Legrand, Y.-M.; Gray, M.; Cooke G.; Rotello, V. M. J. Am. Chem. Soc., 2003, 125, 15789.

3. Reibenspies, J. H.; Guo, F.; Rizzo, C. J. Org. Lett, 2000, 7, 903.

4. Yoneda, F.; Sakuma, Y.; Ichiba, M.; Shinomura, K.; J. Am. Chem. Soc., 1976, 98, 830.

5. Hasford, J. J.; Kemnitzer, W.; Rizzo, C. J. J. Org. Chem., 1997, 62, 5244.

6. Goldner, H.; Dietz, G.; Carstens, E. Liebigs Ann. Chem., 1966, 694, 142.

7. Grande, H. J.; van Schagen, C. G.; Jarbandhan, T.; Müller, F. Helv. Chim. Acta, 1977, 60, 348.

8. Grande, H. J.; Gast, R.; van Schagen, C. G.; van Berkel, W. J. H.; Müller, F. Helv. Chim. Acta, 1977, 60, 367.

9. Monen, C. T. W.; Vervoort, J.; Müller, F. Biochemistry, 1984, 23, 4859.

10. Edwards, A. M.; Saldaño, A.; Bueno, C.; Silva, E.; Alegría, S.; Bol. Soc. Chil. Quím., 2000, $45,423$.

11. López, C.; Claramunt, R. M.; Alkorta, I.; Elguero, J. Spectroscopy, 2000, 14, 121.

12. Berger, S.; Braun, S. 200 and More NMR Experiments; Wiley-VCH: Weinheim, 2004.

13. Spartan '02 Linux/Unix from Wavefunction, Inc.

14. Sheldrick, G. M. SHELX97, Program for Refinement of Crystal Structure, University of Göttingen, Göttingen, Germany, 1997. 